\title{
THE EFFECT OF CHEMICAL TREATMENTS ON THE QUALITY AND LIFE OF VASES IN THE CUT FLOWERS OF CARNATIONS (DIANTHUS CARYOPYLLUS L.)
}

\author{
Tincuța-Marta Gocan ${ }^{1}$, Ileana Andreica ${ }^{1}$, Daniela-Sabina Poșta ${ }^{2}$, Vasile Lazăr ${ }^{1}$, Sándor Rózsa ${ }^{1 *}$, \\ Melinda Rózsa ${ }^{1}$
}

\author{
${ }^{1}$ University of Agricultural Sciences and Veterinary Medicine, \\ Faculty of Horticulture, 400372, 3-5 Mănăştur Street, Cluj-Napoca, Romania \\ ${ }^{2}$ Banat University of Agricultural Sciences and Veterinary Medicine „King Michael I of Romania" from Timisoara, \\ Faculty of Horticulture and Forestry, 119 Aradului Street, 300645 Timisoara, Romania
}

\section{Current Trends in}

\section{Natural Sciences}

\begin{abstract}
The cut flowers are living organs, with intense metabolic activity, subjected to a rapid aging process compared to the undetached flowers from the mother plant. Improving the life of cut flowers is one of the most important factors for customer satisfaction.

The effect of silver thiosulphate (STS) and commercial mixtures was studied in carnation cut flowers and kept in randomized vases according to experimental factors. Three commercial mixtures were used (Chrysal, Flower Food, Fleur Rose) and for thiosulphate four levels (0 or control, 0.03, 0.06 and $0.9 \mathrm{mM}$ ). The interaction of the two factors studied was insignificant for most traits, including wilting percentage and vase lifespan, which may involve the application of both substances alone is sufficient to improve post-harvest quality and is not necessary to use simultaneously in the preservative solution. The results also showed that following the interaction of the two factors, treatment with $0.06 \mathrm{mM}$ silver thiosulphate can be applied to improve the post-harvest quality of blossom cut flowers and commercial chemical mixtures can be successfully replaced.
\end{abstract}

Keywords: carnation, chemical treatments, cut flower, quality, vases life.

\section{INTRODUCTION}

Cut flowers are used to show appreciation, affection and express emotion on various special occasions. International trade in cut flowers has expanded with the promotion and use of horticultural plants for therapeutic benefits, as well as with the current growth of population and consumer demand. In addition to the aesthetic value, the cut flowers were attributed an important commercial and economic value. The market demand for cut flowers is high, especially in the cold periods of the year when consumers' gardens lack these flowers.

The greater the satisfaction and joy of people, the longer the duration of maintaining the quality of cut flowers (Sedaghathoor, 2015). As these are horticultural products, the shelf life is short, various methods and techniques are studied to improve and prolong the shelf life. The literature says that 
the duration of vase decoration of flowers is influenced by variety, species (Table 1) and in a proportion of 2/3 of the way they are treated, handled and stored after harvest (Sidhdharth, 2020). Among the major factors during the production and storage period that influence the life of cut flowers in pots are the relationships with water, carbohydrates, ethylene and pathogens (Gowda, 1990, Darras et al. 2005; Fanourakis et al. 2013).

The storage of cut flowers is important from an economic point of view, as it allows producers to distribute and transport the product to its destination, in order to satisfy the demand of buyers and beneficiaries. During storage both in warehouses and in commercial spaces, a high intensity of respiration of cut flowers is observed. The end of the injured stem, placed in water, quickly depletes the oxygen in the solution vase due to the increased respiration rate of the cells, which ensures a perfect growth condition for microbes (Reid and Jiang 2012). Microbial cells inhibit the functioning of the vascular system through the enzymes produced and vascular tissue and enzymatic activity are affected by the release of toxic metabolites and increased ethylene production (Reid 2002).

Table 1

Storage temperature of various flowers

\begin{tabular}{|l|c|l|}
\hline \multicolumn{1}{|c|}{ Flower species } & $\begin{array}{c}\text { Storage } \\
\text { temperature }\left({ }^{\circ} \mathbf{C}\right)\end{array}$ & \multicolumn{1}{|c|}{ Storage period } \\
\hline Alstroemeria & $3-5$ & 3 days \\
\hline Anthurium & 13 & $3-5$ weeks \\
\hline Chrysanthemum & -0.5 to 0 & $3-5$ weeks \\
\hline Dahlia & $3-5$ & $3-5$ days \\
\hline Dianthus & -0.5 to 0 & 2 weeks \\
\hline Gerbera & 2 & 2 days \\
\hline Gladiolus & $3-4$ & $2-3$ weeks \\
\hline Lily & $0-1$ & 6 weeks \\
\hline Rosa hybrida & $2-5$ & 5 days \\
\hline Tulip & -0.5 to 0 & $2-3$ days \\
\hline
\end{tabular}

Pulsatory treatments prevent vascular infections and inhibit the production of ethylene resulting in a prolonged storage period and a high-quality flower with increased vase life. These treatments are carried out immediately after harvest depending on the species and variety. Silver thiosulphate (STS) acts as an ethylene antagonist and reduces ethylene production and respiration (Veen, 1979) and extends flower longevity (Reid et al., 1980)

By controlling microbial activity in cut flowers (Chanasut et al., 2003), silver thiosulphate improves water absorption. Similarly, Geng et al. (2009) reported that silver thiosulphate improved vessel life and the quality of cut lilies by killing microbes and improving water relations. According to Chikkasubbanna and Yogitha (2002), the treatment of silver thiosulphate reduced the fresh weight loss of rose flowers. Hossini and Chamani (2013) also reported the effect of applying $1 \mathrm{mM}$ silver thiosulphate on reducing flower weight loss. Silver inhibits the synthesis of ethylene (Sedaghathoor, 2015), thus delaying the appearance of wilting. Unlike silver nitrate and silver acetate, which mobilize slowly in plant tissues and decompose after exposure to sunlight, silver thiosulphate is fluid in the branches of cut flowers and moves easily toward the corolla, extending the lifespan of cut flowers (Hadas et al. 1996; Macnish et al. 2004). 
The floral preservative is a mixture of ingredients added to the water of a cut flower to increase the lifespan after harvest. All preservation solutions must essentially contain at least two components; sugar and germicides (Bharti and Verma, 2020). Sugar provides a respiratory substrate, while germicides control harmful bacteria and prevent clogging of conductive tissues (Abdul-Wasea, 2012). A major form of damage to cut flowers is the blockage of xylem vessels in the air and microorganisms that cause the occlusion of the xylem (Hardenburg, 1968). 8-HQS (8hydroxyquinoline citrate) is a very important germicide in preservatives used in the flower industry (Nowak and Rudnicki, 1990) and acts as an antimicrobial agent (Ketsa et al., 1995) that can increase water uptake (Rezvanypour and Osfoor, 2011). It is introduced in most mixtures that accompany the purchased flowers, being recommended to be put in the water of the vases.

Carnation (Dianthus caryophyllus L.) is one of the most important ornamental crops belonging to the family Caryophyllaceae (Tanase et al. 2012; Khatun et al. 2018).

The carnation is mainly used as a cut flower, which is usually classified as a standard type and a spray type. The standard type has a single flower growing on a stem, and the spray type has several flowers growing on a stem (Satoh et al. 2005; Boxriker et al. 2018). The flowers of most standard varieties are double with up to 120 petals (Scovel et al. 1998). Standard varieties are harvested when the flowers are half open or when the outer petal is perpendicular to the stem (Salunkhe et al. 2012).

Carnation is an ethylene-sensitive flower and, if no preservatives are used, its lifespan is normally short (about 7 days) (Satoh et al. 2005; Ali et al. 2012).

In this study we followed the effect of chemical treatments on the quality and life of vases in the carnation cut flowers.

\section{MATERIALS AND METHODS}

The flowers were harvested from a private greenhouse near the city of Cluj-Napoca, Romania. Each lot was packed, containing a number of 20 flowers. They were transferred to the laboratory as soon as possible. In the laboratory, they were placed in a cold room for a short time to obtain the initial heat. Then, they were homogenized in terms of stem length and number of leaves to reduce their differences and minimize experimental error. All stems were cut diagonally to a length of $30 \mathrm{~cm}$. To prevent air from entering the vessels, the cuts were made under water.

In this experiment, $500 \mathrm{ml}$ glass cylinders were used. The basic solution for all treatments, including control treatment, was $350 \mathrm{mg} \mathrm{L}^{-1}$ citric acid $+2.5 \%$ sucrose. For the preparation of citric acid, $15 \mathrm{~g}$ of citric acid were adjusted to $500 \mathrm{ml}$ in a volumetric flask and $15 \mathrm{ml}$ of this solution was applied to each treatment. As for the commercial mixes, nothing was done because they have in the recipe given by the supplier most of the components, their use is recommended by most cut flower suppliers. The same parameters were followed in order to highlight as correctly as possible, the recipe proposed by us. For each variant, 3 flowers were analysed. The temperature was maintained at $21-23{ }^{\circ} \mathrm{C}$. The light from the test site was provided by natural sunlight. The relative humidity was $65-75 \%$. The basic solution (SB) for all treatments, including the control treatment, was $350 \mathrm{mg} \mathrm{L}^{-1}$ citric acid $+2.5 \%$ sucrose. For the preparation of citric acid, $15 \mathrm{~g}$ of citric acid were adjusted to 500 $\mathrm{ml}$ in a volumetric flask and $15 \mathrm{ml}$ of this solution was applied to each treatment. The treatment before the flowers went to the vase lasted 24 hours, the flowers were then introduced into the 500 $\mathrm{ml}$ cylinders only with distilled water. Also, in the flowers where the commercial mixes were used, the water in which they were dissolved was distilled. It should be noted that no water has been changed in any of the containers. 


\section{RESULTS AND DISCUSSIONS}

Results for the physical parameters (Table 2) at the time of setting up the experiment, it is necessary because the flowers were used randomly, differences can be observed for each analysed parameter.

Table 2

Analysed parameters before setting up the experiment

\begin{tabular}{|c|c|c|c|c|}
\hline The nutrient solution & $\begin{array}{c}\text { Floral stem } \\
\text { length }(\mathbf{m m})\end{array}$ & $\begin{array}{c}\text { Sepal length } \\
(\mathbf{m m})\end{array}$ & $\begin{array}{c}\text { Bud base } \\
\text { diameter } \\
(\mathbf{m m})\end{array}$ & $\begin{array}{c}\text { Initial } \\
\text { inflorescence } \\
\text { diameter } \\
(\mathbf{m m})\end{array}$ \\
\hline 0 + SB & 428.12 & 31.40 & 26.60 & 33.97 \\
\hline STS 0.03\%+ SB & 415.73 & 31.12 & 11.95 & 35.55 \\
\hline STS 0.06\%+SB & 402.51 & 20.17 & 12.16 & 34.71 \\
\hline STS 0.09\%+ SB & 462.20 & 27.87 & 20.37 & 31.92 \\
\hline Chrysal & 427.15 & 28.85 & 26.12 & 27.59 \\
\hline Flower Food & 402,19 & 32.16 & 25.32 & 32.40 \\
\hline Fleur Rose & 418.26 & 21.18 & 28.14 & 31.26 \\
\hline
\end{tabular}

From figure 1 where is represented graphically the behaviour as decoration duration (days) in the variants recommended by us and a parallel to those with commercial mixes. It can be seen that in the variant with treatment 3 and 4 the decoration period was close to that of those placed in the commercial mixes. It can be stated that the treatment immediately after harvest had good results being effective. Treatment with STS in combination with sucrose has been shown to be more effective in improving vessel life than with STS or only with sucrose in carnations (Goszynski and Rundnicki, 1982). The combination of sugars and biocides could have extended the life of cut flowers (Halevy and Mayak, 1981).

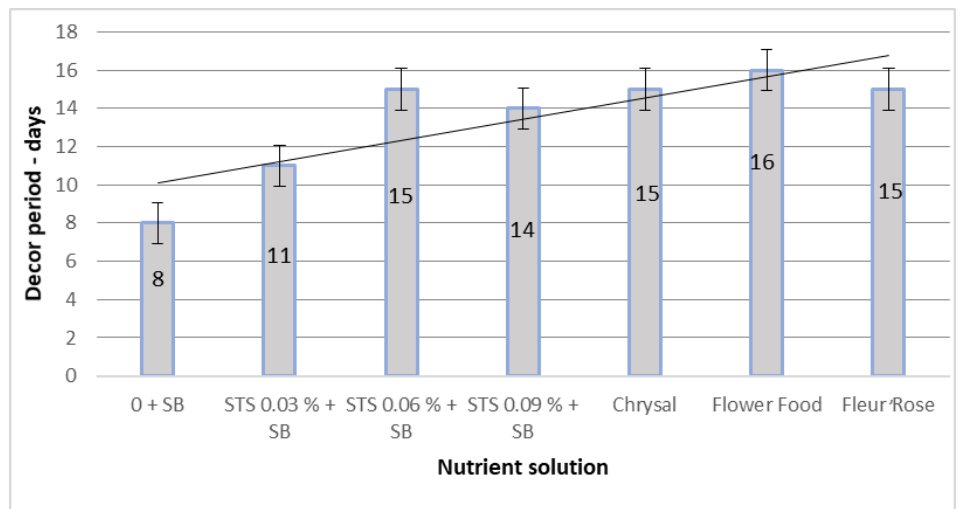

Figure 1. Flower decoration period (days)

The situation of water consumption over the entire period represented graphically in Figure 2 shows the contribution of the proposed treatment and commercial mixes, as they helped the water to penetrate the floral stem and extend the duration of decoration. The effect of the treatment can be observed at a concentration of 0.06 and even at 0.09 the water consumption was close to the maximum value obtained at the commercial Flower Food mix. By controlling the microbial activity 
Current Trends in Natural Sciences

Vol. 10, Issue 20, pp. 165-171, 2021

https://doi.org/10.47068/ctns.2021.v10i20.022

Current Trends in Natural Sciences (on-line)

in cut flowers treated with silver thiosulphate, the water absorption power was improved (Chanasut et al., 2003).

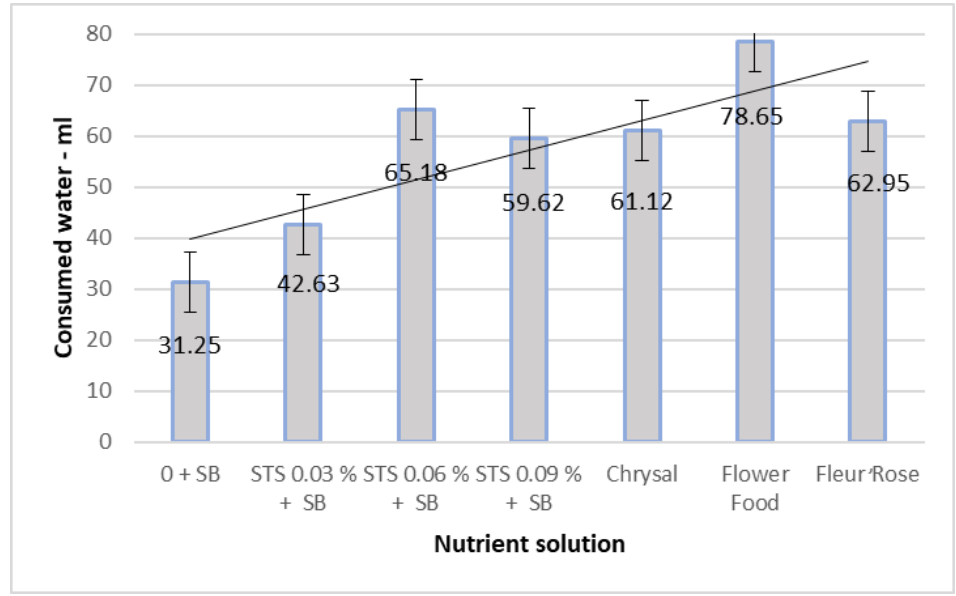

Figure 2. Water consumption under experience (ml)

Early modification of the petals, their discoloration, is an indicator of the quality of the cut carnations that decorate the vase. Similarly, Geng et al. (2009) used silver thiosulfate on lily flowers, where it gave good results. The minimum blackening of the petals (Figure 3) was found when using the Flower Food mix. Also, when treated with $0.06 \%$ STS + SB, the values were very close to those used for commercial mixes.

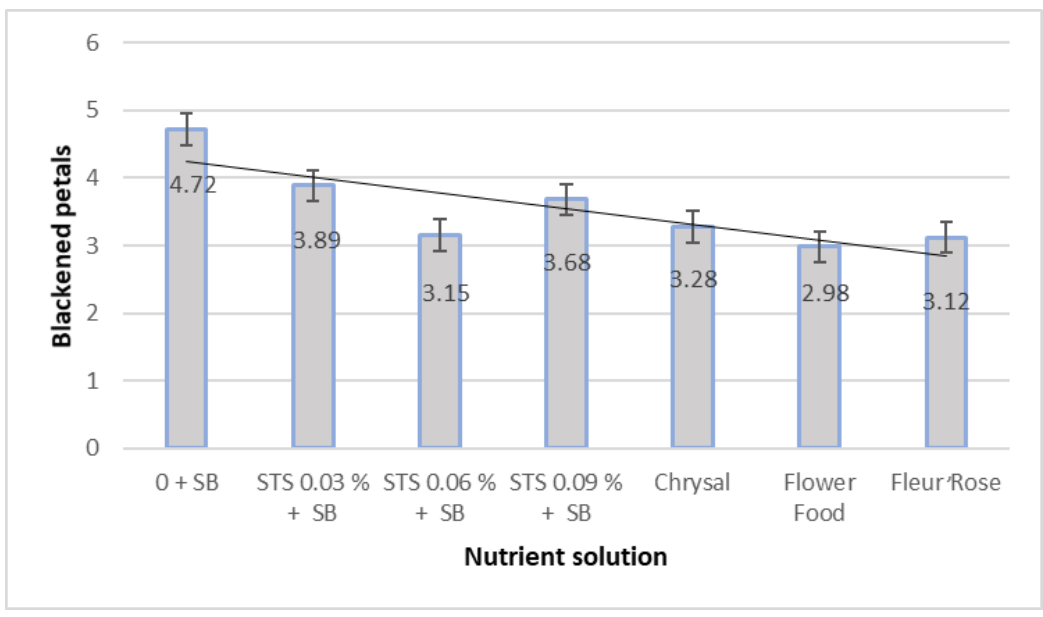

Figure 3. Average of black petals

The decoration period is influenced by the opening pattern of the inflorescences, being presented in Table 1 presents the initial values and Figure 4 presents a parallel between the initial and the final ones. 


\section{Current Trends in Natural Sciences}

Vol. 10, Issue 20, pp. 165-171, 2021

https://doi.org/10.47068/ctns.2021.v10i20.022

Current Trends in Natural Sciences (on-line)

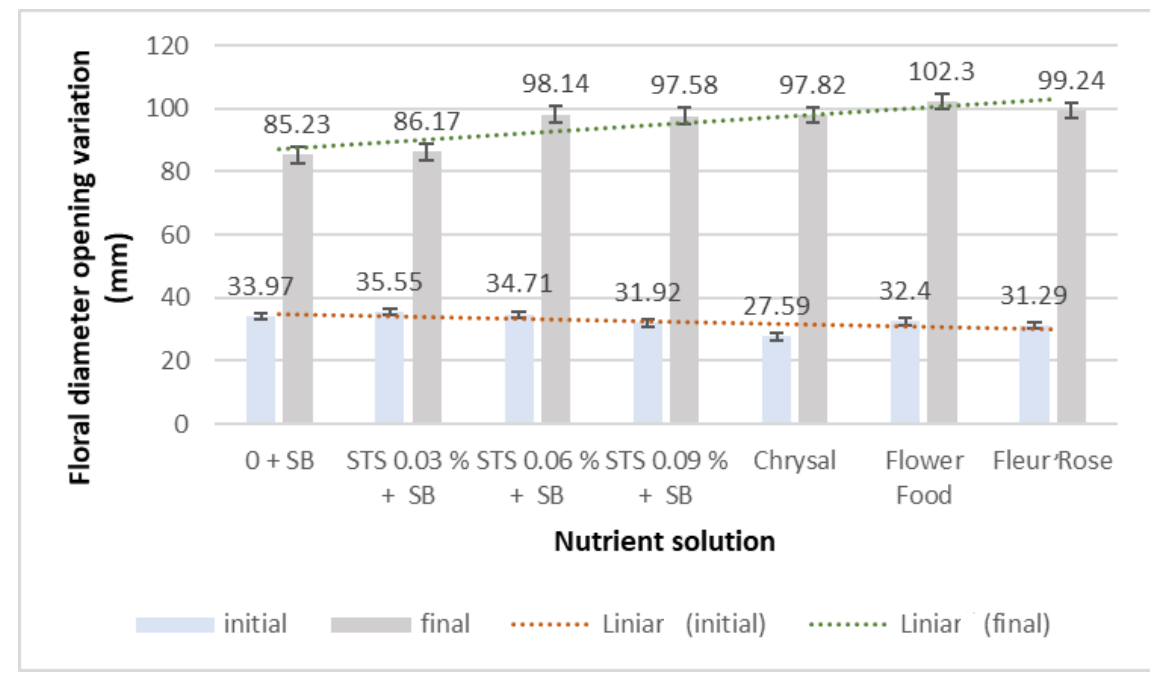

Figure 4. Floral diameter opening variation (mm)

It can be seen that the values at the end of the decoration period ranged from $85.23 \mathrm{~mm}-102.3 \mathrm{~mm}$.

\section{CONCLUSIONS}

The results indicated that the application of silver thiosulphate at a rate of 0.06 and 0.09 immediately after harvest extended the life of carnation cut flowers by increasing the absorption of the solution, increasing the water content of the petals and reducing the percentage of fading. Also, the commercial mixes contributed to the extension of the lifespan of the flowers but, Flower Food was noticed.

Following the results obtained, it can be stated that the application of post-harvest treatments is beneficial for carnations, even if no other substance is added to the water in which they are introduced throughout the decoration period.

\section{REFERENCES}

Abdul-Wasea, A. (2012). Effects of some preservative solutions on vase life and keeping quality of snapdragon (Antirrhinum majus L.) cut flowers, Journal of the Saudi Society of Agricultural Sciences 11, 29-35.

Ali, A.H., Afrasiab, S., Naz, M. Rauf and J. Iqbal. (2008). An efficient protocol for in vitro propagation of carnation (Dianthus caryophyllus). Pak. J. Bot. 40,111-121.

Bharti Sao and LS Verma (2020). Review on impact of different preservative solutions on vase-life of tuberose (Polianthes tuberosa L.) cut flowers, Journal of harmacognosy and Phytochemistry 9(1), 1185-1188.

Boxriker, M., Möhring, J. and Piepho, H.P. (2018). Genetic and phenotypic correlation for breeding relevant traits in Dianthus caryophyllus L. Postharvest Biology and Technology, 143, pp.129-136.

Çelikel, F.G. and Reid, M.S. (2002). Storage temperature affects the quality of cut flowers from the Asteraceae, HortScience, 37(1), pp.148-150.

Chanasut, U., Rogers, H.J., Leverenttz, M.K., Griffiths, G., Thomas, B., Wagstaff, C. Stead, A. D. (2003). Increasing flower longevity in Alstroemeria. Postharvest Physiology and Technology, 29(3), 324-332.

Chikkasubbanna, V., Yogitha, N. (2002). Extension of vase life of cut roses cultivars cream prophyta and sacha. Crop Research Hisar, 24(1), 40-44.

Darras, A.I., Terry, L.A. and Joyce, D.C. (2005). Methyl jasmonate vapour treatment suppresses specking caused by Botrytis cinerea on cut Freesia hybrida L. flowers, Post-harvest Biology and Technology, 38(2), pp.175-182.

Fanourakis, D., Pieruschka, R., Savvides, A., Macnish, A.J., Sarlikioti, V. and Woltering, E.J. (2013). Sources of vase life variation in cut roses: a review, Postharvest Biology and Technology, 78, pp.1-15. 


\section{Current Trends in Natural Sciences}

Vol. 10, Issue 20, pp. 165-171, 2021

https://doi.org/10.47068/ctns.2021.v10i20.022

Current Trends in Natural Sciences (on-line)

ISSN: 2284-953X

Current Trends in Natural Sciences (CD-Rom)

ISSN: 2284-9521

ISSN-L: 2284-9521

ISSN-L: 2284-9521

Geng, X. M., Liu, J., Lu, J. G., Hu, F. R., \& Okubo, H. (2009). Effects of cold storage and different pulsing treatments on postharvest quality of cut OT lily I Mantissa' flowers. Journal of the Faculty of Agriculture, Kyushu University, 54(1), 41-45.

Gowda JVN. (1990). Effect of surcrose and aluminum sulphate on the postharvest life of tuberose double. Current Res. Univ. Agr. Sci. Bangalor 19, 14-16.

Hardenburg, R.E., (1968). The commercial storage of fruits, vegetables and florist and nursery stock. In: Lutz, J.M. (Ed.), Agricultural Handbook No. 66. Department of Agriculture. Agricultural Research Sevice, United State, p. 130.

Hossini D.S., and Chamani, E. (2013). An Investigasion of the possible improvement of cut rose flower cv. 'Red Old' longevity employing organic treatments vs. silver thiosulfate. Iranian Journal of Horticultural Science, 44(1), $31-41$.

Ketsa, S., Piyasaengthong, Y., Parthuangwong, S., (1995). Mode of action of $\mathrm{AgNO}_{3}$ in maximizing vase life of Dendrobium Pompodour flowers. Postharvest Biol. Technol. 5, 109-117.

Khatun, M.M., Roy, P.K. and Razzak, M.A., (2018), Additive effects of coconut water with various hormones on invitro regeneration of carnation (Dianthus caryophyllus L), Journal of animal and plant sciences, 28(2), pp.589596.

Macnish, A.J., Joyce, D.C., Inving, D.E., Wearing, A.H. (2004). A simple sustained release device for the ethylene binding inhibitor 1-methylcyclopropene. Postharvest Biology and Technology, 32(3), 321-338.

Nowak J, Rudnicki R.M. (1990). Postharvest handling and storage of cut flower, florist, greens and potted plants. Timber Press Inc., pp. 39-43.

Reid R.Y., Evans R.Y., Dodge L.L. (1980). Ethylene and silver thiosulphate influence opening of cut rose flowers. $J$ Am. Soc. Hortic. Sci. 114(3), 436-440.

Reid, M.S. and Jiang, C.Z. (2012). Postharvest biology and technology of cut flowers and potted plants, Horticultural Reviews, 40, pp.1-54.

Reid, M.S. (2002). Postharvest handling systems: ornamental crops, Postharvest technology of horticultural crops, pp.315-325.

Rezvanypour, S., \& Osfoor, M. (2011). Effect of chemical treatments and sucrose on vase life of three cut rose cultivars. Journal of Research in Agricultural Science, 7(2), 133-139.

Salunkhe, D.K., Bhat, N.R. and Desai, B.B. (2012). Postharvest biotechnology of flowers and ornamental plants, Springer Science \& Business Media.

Satoh, S., Nukui, H. and Inokuma, T. (2005). A method for determining the vase life of cut spray carnation flowers, Journal of Applied Horticulture, 7(1), pp.8-10.

Scovel, G., Ben-Meir, H., Ovadis, M., Itzhaki, H. and Vainstein, A. (1998). RAPD and RFLP markers tightly linked to the locus controlling carnation (Dianthus caryophyllus) lower type, Theoretical and applied genetics, 96(1), pp.117-122.

Sedaghathoor, S. (2015). Effect of wall colors and nanosilver treatment on the vase life of cut carnation "Express". Journal of Ornamental and Horticultural Plants, 5(1), 1-6.

Sidhdharth, G., Nivethaa, P.J. (2020). Ethylene, Water and Sugar-An Influence in Vase Life of Cut Flowers. Biotica Research Today, 2(12), 1265-1267.

Tanase, K., Nishitani, C., Hirakawa, H., Isobe, S., Tabata, S., Ohmiya, A. and Onozaki, T. (2012). Transcriptome analysis of carnation (Dianthus caryophyllus L.) based on next-generation sequencing technology, BMC genomics, 13(1), pp.292.

Veen, H. (1979). Effects of silver on ethylene synthesis and action in cut carnations. Planta, 145(5), 467-470. 